Sitasi artikel ini (APA $6^{\text {th }}$ Edition style):

Gultom, A. Z. (2018). Situs Arkeologis Kota Rentang dan Jejak Kemaritiman Masa Lampau. MUKADIMAH, 2(1), 20-27.

\title{
Situs Arkeologis Kota Rentang dan Jejak Kemaritiman Masa Lampau
}

\author{
Adam Zaki Gultom \\ Guru Sejarah SMK Multi Karya, Medan \\ azaki279@gmail.com
}

\begin{abstract}
ABSTRAK
Peradaban pesisir timur Sumatera terjadi akibat dari aktivitas perdagangan yang terjadi di kawasan sepanjang pesisir. Peradaban masa lampau tentulah meninggalkan jejak-jejak kehidupannya berupa fragmen keramik, tembikar, bangunan, bata, nisan dan sebagainya. Di Pesisir timur Sumatera Utara terdapat satu kawasan situs, yaitu Situs Kota Rentang yang dahulunya merupakan kawasan perdagangan yang aktif pada masa lampau. Kawasan ini menjadi salah satu poros peradaban di Sumatera Utara selain Pulau Kampai dan Situs Kota Cina. Dengan banyaknya temuan arkeologis di kawasan ini membuktikan bahwa kawasan ini dahulunya ramai didatangi pedagang-pedagang luar nusantara untuk melakukan proses niaga dengan pedagang setempat. Hal ini tentu saja membuat terjadinya interaksi lokal dengan internasional, yang mempengaruhi cerita sejarah di Sumatera Utara.
\end{abstract}

Kata kunci: situs arkeologis, Kota Rentang, kemaritiman.

\section{PENDAHULUAN}

Aktivitas perdagangan yang terjadi melalui jalur laut tidak dapat dipisahkan dari letak strategis lokasi situs-situs yang ditemukan di pesisir timur Sumatera yang secara langsung berhadapan dengan selat Malaka. Selat Malaka merupakan jalur perdagangan laut yang ramai dalam rentang waktu yang panjang (mulai abad permulaan masehi hingga abad ke-19). Perdagangan melalui laut memanfaatkan kemajuan teknologi kelautan dengan penggunaan perahu-perahu dagang bermuatan besar yang memanfaatkan navigasi angin muson. Selat Malaka merupakan jalur sutera laut yang pada awalnya merupakan jalur perdagangan alternatif setelah jalur sutera darat yang menghubungkan Cina dengan daerah India. Seiring dengan perjalanan waktu, serta perkembangan teknologi pelayaran, Selat Malaka menjadi jalur perdagangan utama menuju daerah penghasil rempah-rempah, kapur barus, emas, kayu cendana, maupun barang niaga lainnya di wilayah Nusantara. 
Pesisir timur Sumatera yang tepat dilewati ke Selat Malaka memiliki potensi data arkeologis yang melimpah. Melimpahnya data arkeologi tersebut dikaitkan dengan jejak kejayaan aktivitas maritim masa lalu di pesisir timur Sumatera dalam konteks interaksi manusia dan budayanya. Data arkeologi yang ditemukan di kawasan ini bisa dikatakan cukup banyak dipublikasikan. Gambaran umum hasil publikasi ilmiah yang telah dilakukan memberikan gambaran kondisi masing-masing lokasi tersebut menyangkut adanya dinamika dan kesinambungan aktivitas maritim yang cukup lama serta intensitas yang tinggi di wilayah pesisir timur Sumatera. Data arkeologis yang ditemukan tidak hanya mencerminkan sisa sampah hasil aktivitas manusia dengan tujuan untuk menunjukankan lokasi beraktivitas manusia saja, tetapi juga dapat menggambarkan ramainya pesisir timur Sumatera di masa lalu di mana terjadi interaksi antar bangsa. Data arkeologi yang ditemukan di masingmasing tempat merupakan dasar untuk menentukan asal data arkeologi, serta menentukan karakteristik masing-masing jenis data, tetapi juga untuk menentukan rentang waktu kawasan tersebut dijadikan sebagai kawasan aktivitas manusia pada masa lampau.

Kota Rentang diyakini merupakan bandar yang super sibuk karena tepat berada di samping sungai Dalu yang bermuara ke laut Belawan. Pada akhirnya kota ini jatuh atas gempuran pasukan Aceh dan menyingkir ke daerah Deli Tua, di sebelah timur Medan. Dari sana, lintasan peradaban tua Medan menjadi punah selama-lamanya dan hanya dapat direkontruksi dengan melakukan penelitian berkesinambungan sehingga tautan antar periodisasi sejarah dapat dibentangkan. Aktivitas kemaritiman di pesisir timur Sumatera tidak hanya memunculkan satu lokasi dan satu kurun waktu tertentu sebagai simpul yang berdiri sendiri. Indikasi adanya dinamika, keterkaitan, dan kesinambungan pemanfaatan pesisir timur Sumatera dalam aktivitas kemaritiman dan interaksi antar bangsa dan budaya yang terjadi di masa lalu cukup besar. Penelitian arkeologis yang cukup intensif telah dilakukan di situs-situs Pulau Kampai, Kota Cina, dan Kota Rantang beberapa waktu berselang menghasilkan data yang cukup menarik. Informasi yang diperoleh melalui data dimaksud menunjukkan keberadaan kegiatan pelayaran dan perdagangan, juga pengenalan akan beberapa aspek kehidupan, serta kronologi yang cukup sahih (Koestoro, Purnawibowo, \& Oetomo, 2016).

Kejayaan Situs Kota Rentang pada masa lampau yang merupakan salah satu tempat terpenting di pesisir timur Sumatera kini tidak nampak lagi. Kurangnya pengetahuan masyarakat setempat tentang sejarah dari situs ini menyebabkan kawasan ini tak ubahnya hanya hamparan persawahan, kebun sawit dan tambak ikan. Hal ini diperparah dengan sikap kurang pedulinya pemerintah terhadap situs-situs cagar budaya yang ada di Sumatera Utara, sehingga tidak jarang situs-situs yang ditemukan di Sumatera Utara dengan kondisi yang tidak terawat dan bahkan hampir dikatakan hilang. Padahal jika ada perhatian pemerintah dan masyarakat terhadap situs yang ada di daerah mereka, tidak menutup kemungkinan bisa menjadi menjadi destinasi wisatawan yang berkunjung ke Sumatera Utara. Dan tentu saja akan berdampak pada kehidupan perekonomian masyarakat setempat. Kondisi situs kota rentang saat 
ini bisa bilang sangat memprihatinkan, banyak lahan-lahan yang diindikasi terdapat temuan-temuan kuno berubah fungsi menjadi tambak ikan, dimana dalam proses pembuatannya menggunakan alat berat sehingga tidak menutup kemungkinan temuan-temuan yang masih utuh menjadi rusak. Selain itu, pola pikir masyarakat masih kental dengan hal mistis. Hal tersebut dapat dilihat dengan batu nisan kuno yang ada di kawasan ini banyak yang hilang.

\section{HASIL DAN PEMBAHASAN}

\section{Situs Kota Rentang}

Kota Rentang adalah desa yang terletak di Kecamatan Hamparan Perak, Kabupaten Deli Serdang, Sumatera Utara. Kota Rantang merupakan kawasan pesisir Pulau Sumatera Utara. Terletak di posisi 30 43' Lintang Utara dan 980 38' Bujur Timur yang dapat dicapai dari Kota Medan setelah menyusuri tepi Sungai Deli sejauh $14 \mathrm{~km}$ ke arah Utara/Belawan, dan kemudian menyeberangi sungai Deli sejauh $2 \mathrm{~km}$ ke arah Barat. Situs ini terletak pada 1,5 meter dari permukaan laut (dpl) dan kawasan ini merupakan lahan rawa yang banyak dipengaruhi pasang surut air laut, hal tersebut dapat dirasakan kira-kira 2 kilometer dari pemukiman penduduk, dimana airnya merupakan air asin. Lokasi situs ini terletak di $15 \mathrm{~km}$ arah barat laut dari Kota Medan. Di Desa Kota Rentang terdapat sungai kecil yang alirannya merupkan pertemuan dari Sungai Diski dan Sungai Semayang. Agar sampai ke kawasan ini, kita harus melewati jalan perkebunan tebu milik PT. Nusantara II yang terletak di Desa Klambir Lima.

Diperkirakan dahulunya daerah ini merupakan sebagai salah satu kawasan perdagangan di pesisir timur Pulau Sumatera. Didukung dengan adanya temuan arkeologis di situs Kota Rentang, hal ini membuktikan bahwa peradaban masa lalu sudah berlangsung lama yang pernah ada di kawasan ini. Dengan temuan-temuan yang didapatkan di situs ini, mengindikasikan adanya kontak pelayaran dan perdagangan dengan masyarakat pedalaman dan masyarakat luar yang berlangsung di pesisir Sumatera yang secara langsung mempertemukan masyarakat pedalaman (menghasilkan berbagai komoditas) membawa barang yang diperlukan para pendatang yang berasal dari penjuru dunia dari luar pulau Sumatera. Bukan hanya pedagang lokal saja yang diuntungkan dengan kedatangan pedagang luar ini, tetapi masyarakat lokal juga diuntungkan, dikarenakan kebutuhan masyarakat setempat juga dipenuhi oleh pedagang-pedagang yang datang membawa berbagai barang yang tidak dihasilkan atau diproduksi di Sumatera, khususnya Sumatera Utara.

Bukti bahwa kawasan ini merupakan salah satu kawasan yang penting pada masanya adalah dengan ditemukannya berbagai temuan yang merupakan bagian dari aktivitas pada masa lalu seperti keramik, tembikar, batu-batuan dan bahkan nisan yang bisa dijadikan sebagai sumber penggalian informasi tentang masa kejayaan atau kehidupan yang terjadi di kawasaan ini pada masa lampau. Aneka keramik yang ditemukan peneliti paling banyak berasal dari Dinasti Yuan abad ke-13-14. Ada juga temuan keramik dari Dinasti Ming abad ke-15, keramik Vietnam abad ke-14-16, keramik Thailand abad ke-14-16, 
keramik Burma abad ke-14-16, dan keramik Khmer abad ke-12- 14. Adapun batu nisan yang ada di lokasi bergaya Islam dengan bertuliskan syahadat tanpa ada angka tahun. Di sekitar lokasi, juga terdapat batu bata yang diduga bahan bangunan sebuah candi. Namun, belum dapat dipastikan apakah batu bata merah itu potongan candi. Batu-bata itu terkonsentrasi di sebuah gundukan tanah dengan sarang rayap di sekitarnya (Damanik, 2008).

Situs Kota Rentang secara administratif berada di wilayah Desa Kota Rantang, Kecamatan Hamparan Perak, Kabupaten Deli Serdang. Lahan situs Kota Rentang merupakan dataran aluvial yang terbentuk dari hasil sedimentasi Sungai Hitam (Arangdalu) dan Sungai Paya Puntung yang bermuara ke Sungai Belawan. Sebagian besar masyarakat yang berdiam di areal situs mengusahakan lahannya sebagai areal persawahan, perkebunan kelapa, kelapa sawit, kakao; maupun usaha perikanan dengan membuka tambak atau kolam ikan. Ketika Edmund Edward McKinnon meninjau situs ini pada tahun 1972, dilihatnya sejumlah nisan Batu Aceh dan 2 pecahan mangkuk keramik dari masa awal Dinasti Ming (abad ke-14), masing-masing berasal dari kiln (tungku pembakaran) Longquan dan Jingdezhen (McKinnon, 1994).

Namun, ketika pada tahun 2005 McKinnon meninjau ulang situs ini, sebagian besar nisan Batu Aceh yang pernah dilihatnya pada tahun 1972 telah hilang; hanya sebagian kecil yang tersisa di beberapa lokasi. Pada tahun 2008, satu tim arkeologi yang terdiri dari para peneliti dari Pusat Penelitian dan Pengembangan Arkeologi Nasional, Balai Arkeologi Medan, Museum Negeri Provinsi Sumatera Utara, Asia Research Institute (National University Singapore), dan Boston University, melakukan penelitian sistematis pertama kali terhadap situs Kota Rentang. Penelitian tahun 2008 tersebut telah berhasil sejumlah aspek kehidupan manusia masa lalu yang jejak-jejaknya berupa artefak dan ekofak yang tersebar di permukaan dan di bawah tanah. Ragam keramik dan tembikar yang ditemukan merupakan petunjuk interaksi penghuni situs ini di masa lalu dengan para pendatang dari Asia Tenggara daratan dan Cina. Selain itu juga ditemukan petunjuk keberadaan hunian kuno, yang didasarkan atas temuan data ekofak berupa tonggak tonggak kayu yang diduga adalah tiang-tiang rumah di lahan pasang surut (Soedewo et al., 2011).

Dengan ditemukannya makam-makam kuno di kawasan Situs Kota Rentang, membuktikan bahwa kawasan ini mendapat pengaruh Islam. Tidak menutup kemungkinan kawasan ini bisa memecahkan teka-teki tentang masuknya Islam di wilayah pesisir Medan, untuk hal tersebut perlu dilakukan penelitian lebih lanjut. Dengan temuan tersebut, maka bukan hal yang tidak mungkin bahwa kawasan ini merupakan kawasan yang sangat berpengaruh pada masanya. Dengan kondisi situs yang kurang perhatian, tidak menutup kemungkinan untuk dilakukan penelitian yang lebih mendalam tentang kawasan ini dan memberikan pengetahuan yang luas tentang kejayaan kawasan ini di pesisir timur Sumatera. Serta kita dapat menunjukkan pada generasi-generasi penerus bahwa di Sumatera Utara pernah muncul peradaban yang penting pada masa lampau. 


\section{Temuan Artefak Keramik, Tembikar dan Bata Situs Kota Rentang}

Pemerolehan data kepurbakalaan di situs Kota Rentang dilakukan melalui survei permukaan, untuk mengetahui sebaran artefak yang tampak di permukaan tanah guna mengetahui keberadaan sejumlah nisan kuno dan artefak lain sebagaimana disebutkan oleh McKinnon melalui observasinya di tahun 1972. Dalam observasinya tersebut McKinnon berhasil menemukan 2 pecahan mangkuk keramik dari masa awal Dinasti Ming, masing-masing adalah keramik Zhejiang Longquan, dan keramik Jiangxi Jingdezhen biru putih. Keduanya berasal dari awal abad ke-15 M, yang artinya semasa dengan saat muhibah armada Ming ke selatan di bawah Laksamana Cheng Ho (Soedewo et al., 2011).

Penelitian Situs Kota Rantang dilakukan oleh Tim Peneliti Arkeologi dari Pusat Penelitian dan Pengembangan Arkeologi Nasional Jakarta pada bulan April 2008. Tim Peneliti yang terbentuk melakukan penelitian selama 12 hari di di desa "Mojopahit". Menurut Nani H. Wibisono, koordinator eskavasi, ditemukan pecahan batu nisan dan beberapa pecahan keramik dari Dinasti Yuan abad ke-13 sampai abad ke-14; Dinasti Ming abad ke-15, keramik Vietnam abad ke-14 sampai abad ke-16, keramik Thailand abad ke-14 sampai abad ke-16, keramik Burma abad ke- 14 sampai abad ke-16, dan keramik Khmer abad ke-12 sampai abad ke-14. Adapun batu nisan yang ada di lokasi bertuliskan syahadat tanpa tarikh. Walau demikian, makam-makam kuno yang diteliti bukan di desa Mojopahit, tetapi di beberapa lokasi yaitu di Dusun II Kota Rantang Luar.

Selain ditemukan fragmen keramik, di kawasan ini juga ditemukan fragmen tembikar. Sejumlah fragmen tembikar yang berhasil ditemukan melalui survei permukaan terdiri dari beragam bentuk, bahan, warna, dan kualitas. Keragaman tersebut selain merupakan cerminan tingkat teknologi dan kreativitas pembuatnya, juga dapat dijadikan petunjuk tentang asal benda maupun rentang masa relatif pemanfaatan kawasan Kota Rentang di masa lalu. Tembikar yang ditemukan di situs Kota Rentang banyak bercorak India Selatan abad 13-15 M, tetapi tidak menutup kemungkinan ditemukan tembikar lain, hal ini dikemukankan Ery Soedewo dengan ditemukannya fragmen tembikar halus bagian bibir; berdiameter $14 \mathrm{~cm}$, tebal 0,8 cm; warna krem pucat; di pangkal sisi dalam, terdapat sepasang goresan horizontal; kemungkinan merupakan bagian bibir dari kuali atau kendi berbahan halus, yang berasal dari daratan Asia Tenggara khususnya kawasan sekitar Satingphra di Teluk Siam, mulai diproduksi setidaknya pada abad ke-11 atau ke-12. Selain ditemukan di situs Kota Rentang benda sejenis juga ditemukan di situs Kota Cina dan situs Bukit Hasang (Barus) (Soedewo et al., 2011). Merujuk pada hasil kajian Daniel Perret untuk sementara dapat dinyatakan bahwa benda ini adalah kuali dari India Selatan yang diproduksi antara abad ke-13 hingga ke-15. Keberadaan tiga benda sejenis yang berasal dari India Selatan menjadi petunjuk keterkaitan tempat-tempat di mana benda-benda ini ditemukan (Barus, Kota Rentang, dan Kota Cina) dengan kawasan selatan anak benua/India pada masa lalu (Perret, 2010, pp. 198-199). 
Penggalian-penggalian dalam rangka mencari temuan-temuan kuno yang dilakukan oleh tim peneliti Balai Arkeologi yang bekerjasama dengan pihak lain, tidak hanya menemukan fragmen keramik ataupun tembikar. Para peneliti juga menemukan bata kuno, dengan ditemukan bata kuno ini merupakan hal yang unik, yaitu tentang bagaimana proses pembuatannya dan apa fungsinya pada masa lampau, sebab penduduk pesisir pada masa lampau identik dengan bangunan berbahan kayu. Ditambah lagi dengan tekstur tanah pesisir yang tidak memungkinkan sebagai bahan baku pembuatan batu bata. Temuan-temuan bata di situs kota Rentang di jelaskan oleh Ery Soedewo (Soedewo et al., 2011), sebagai berikut :

1) Fragmen bata berukuran panjang $20,5 \mathrm{~cm}$, lebar $17 \mathrm{~cm}$, dan tebal $6 \mathrm{~cm}$; ditemukan di suatu gundukan di areal persawahan tidak jauh dari Pulo Mojopahit yang berada di selatannya. Di areal ini masih terdapat sisa struktur yang masih terpendam, yang terlihat dari singkapan di sisi utara gundukan tanah ini.

2) Fragmen bata berukuran panjang $19 \mathrm{~cm}$, lebar $12,5 \mathrm{~cm}$, dan tebal $6 \mathrm{~cm}$; ditemukan di suatu gundukan di areal persawahan tidak jauh dari Pulo Mojopahit yang berada di selatannya. Di areal ini masih terdapat sisa struktur yang masih terpendam, yang terlihat dari singkapan di sisi utara gundukan tanah ini.

\section{Makam Kuno di Kota Rentang}

Selain ditemukan artefak seperti keramik, tembikar dan bahkan bata kuno, dimana benda-benda tersebut masih terkubur di dalam tanah, tetapi juga ditemukan batu-batu nisan yang diperkirakan berasal dari Kerajaan Samudera Pasai itu, yang jumlahnya tidak diketahui secara pasti. Dengan temuan nisanisan ini mengindikasikan pengaruh Islam tentulah ada di kawasan ini. Hal ini dijelaskan oleh Suprayitno bahwa di Sumatera Utara, khususnya di sekitar kota Medan tidak banyak dijumpai situs makam kuno. Sejauh ini hanya enam makam saja yang pernah dijumpai di kawasan ini. Makam itu adalah di Klumpang, Kota Rantang, Hamparan Perak, Kabupaten Deli Serdang serta Mabar, Sukamulia di Kotamadya Medan, Pulau Kampai, Kabupaten Langkat dan Kompleks Makam di Barus. Makam di Klumpang, Mabar, dan Sukamulia tidak dapat diketahui lagi keberadaannya (Suprayitno, 2012).

Soedewo menjelaskan makam-makam di kawasan Kota Rentang umumnya pemakaman bersama dengan kelompok makam yang diberi tanda batu nisan untuk bagian kepala dan kaki makam, walaupun sering ditemukan pula makam yang hanya diberi tanda pada bagian kepala makam saja. Pemilihan lokasi pemakaman di tempat yang lebih tinggi di kawasan rawa berair tawar dan payau serupa tanggul-tanggul alam yang terbentuk melalui proses sedimentasi. Tanggul alam ini terbentuk akibat pengendapan oleh lumpur yang hanyut saat musim hujan serta pasang naik dan surut permukaan air laut. Jenis batuan di kawasan berawa ini berupa tanah gambut akibat proses pembusukan vegetasi habitat rawa yang bercampur lumpur dan butiran pasir kuarsa halus. Makam kuno merupakan kelompok pemakaman bersama, 
mungkin makam dari satu keluarga. Suatu kelompok makam bersama terdiri dari dua hingga enam atau tujuh makam. Namun, ada pula makam yang hanya satu dan terpisah jauh dari kelompok makam lainnya. Pemakaman seperti ini dapat dihubungkan sebagai pemakaman bersama milik 'pemakaman keluarga', atau setidaknya kompleks pemakaman itu adalah makam sesama muslim, karena sesama muslim merupakan saudara atau satu keluarga. Tradisi pemakaman bersama atau makam keluarga ini juga sering ditemukan di kawasan Geudong atau di Aceh Utara umumnya (Soedewo et al., 2011).

Makam-makam kuno di Kota Rantang tersebut tersebar di tiga tempat yang dihubungkan dengan dua sungai berair tawar. Keseluruhannya berjumlah 12 pemakaman dan 40 makam, namun dari hasil pengamatan diketahui hanya 38 yang dapat dikenali sebagai batu nisan tipe Aceh atau Batu Aceh dari masa Samudera Pasai. Makam-makam kuno itu dari utara ke selatan, yaitu;

1) Lokasi A; di barat-utara, diantara pertemuan sungai Diski dan sungai Arandalu; terdiri dari 3 (tiga) pemakaman dengan 7 makam.

2) Lokasi B; di antara sungai Diski dan sungai Arandalu; terdiri 5 (lima) pemakaman dengan 23 makam.

3) Lokasi C; di timur sungai Arandalu; terdiri dari 4 (empat) pemakaman dengan 10 makam.

Makam ini ditemukan di tanah sedimentasi yang tinggi membentuk tanggul alam, serupa pulau saat digenangi air. Namun, sekarang hampir seluruh lahan yang ada dimanfaatkan oleh masyarakat setempat untuk menanam padi dan tanaman industri, terutama kelapa sawit dan cacao. Kegiatan masyarakat itu telah dimulai sejak tahun 1958-1960-an. Karena ketidaktahuan masyarakat saat mempersiapkan lahan garapan tersebut, banyak batu nisan yang digusur dan tidak lagi pada posisi semula, bahkan tidak diketahui lagi keberadaannya (Soedewo et al., 2011).

Kedudukan situs makam sangat memprihatinkan; makam ke-1 bahkan salah satu batu nisannya ada berhias sauh kapal sudah hilang. Makam ke-2, sebagiannya telah dibongkar orang, karena dipercayai di bawah makam terdapat harta karun. Makam ke-3, bernasib sama, batu nisan sudah banyak yang tercabut dan terbiar di semak belukar. Makam ke-4, lebih buruk pula karena sudah tertimbun sampah kilang padi. Penduduk setempat tidak mengenali siapa yang dikuburkan di makam-makam tersebut, termasuk sejarah makam. Walau demikian menurut keterangan penduduk, di kawasan ini pada tahun 1990, masih nampak tiang kapal tertanam di tengah rawa-rawa, tapi sekarang sudah tidak kelihatan.

\section{PENUTUP}

Situs Kota Rentang diperkirakan dahulunya merupakan sebagai salah satu kawasan perdagangan di pesisir timur Pulau Sumatera. Hal ini di dukung dengan adanya temuan arkeologis di situs Kota Rentang berupa fragmen keramik abad 12-16, fragmen tembikar abad 13-15, batu nisan kuno yang 
memiliki corak yang sama dengan nisan di Aceh dan temuan batu bata yang belum diketahui fungsinya. Dengan temuan tersebut, membuktikan bahwa aktivitas masa lalu sudah berlangsung lama yang pernah ada di kawasan ini. Dengan temuan-temuan yang didapatkan di situs ini, mengindikasikan adanya kontak pelayaran dan perdagangan dengan masyarakat pedalaman dan masyarakat luar yang berlangsung di pesisir Sumatera yang secara langsung mempertemukan masyarakat pedalaman (menghasilkan berbagai komoditas) membawa barang yang diperlukan para pendatang yang berasal dari penjuru dunia dari luar pulau Sumatera.

Namun masa lalu tetap menjadi masa lalu, kondisi kawasan Situs Kota Rentang saat ini sangat memprihatinkan. Situs ini terancam hilang dengan aktivitas masyarakat yang tinggal di daerah tersebut. Ketidaktahuan masyarakat tentang sejarah tempat mereka tinggal serta kurangnya perhatian pemerintah terhadap situs ini membuatnya menjadi kawasan tanpa nilai sejarah. Hal ini terlihat dari banyaknya tambak-tambak ikan yang dibuka oleh warga serta banyaknya tanaman kelapa sawit yang tumbuh di atas situs. Belum lagi nisan-nisan kuno yang tidak diketahui jejaknya, karena anggapan hal mistis tentang nisan-nisan ini membuat situs ini semakin menghilang. Perlu adanya kesadaran masyarakat dan pemerintah untuk menjaga kawasan situs yang penuh dengan nilai-nilai sejarah ini. Jika kita tidak menjaga keberadaan situs-situs bersejarah di Sumatera Utara kelak anak cucu kita tidak mengetahui besarnya peninggalan masa lalu di bumi Andalas.

\section{REFERENSI}

Damanik, E. L. (2008). Situs Kota Rentang. Retrieved from https:/ /ipie3.wordpress.com/2008/12/18/situs-sejarah-kota-rentang/

Koestoro, L. P., Purnawibowo, S., \& Oetomo, R. W. (2016). Dinamika Aktivitas Kemaritiman di Pulau Kampai, Kota Cina, dan Kota Rantang, Sumatera Utara. Sangkhakala Balai Arkeologi, 19(2), 96-109.

McKinnon, E. E. (1994). Yue and Longquan Wares in Sumatra. New Light on Chinese Yue and Longquan Wares Hong Kong: University of Hong Kong Centre of Asian Studies, 284-298.

Perret, D. (2010). Kolonialisme dan Etnisitas: Batak dan Melayu di Sumatra Timur Laut. Jakarta: KPG.

Soedewo, E., Satria, D., Damanik, E., Nisa, K., Hasanuddin, \& Situngkir, B. (2011). Penelitian Situs Dunia di Sumatera Utara: Kota Rentang dan Pulau Kampai. In M. N. S. Utara (Ed.), Penelitian Situs Dunia Di Sumatera Utara : Kota Rentang dan Pulau Kampai (pp. 3-4). Medan: Museum Negeri Sumatera Utara.

Suprayitno, S. (2012). Islamisasi di Sumatera Utara: Studi Tentang Batu Nisan di Kota Rantang dan Barus. MIQOT: Jurnal Ilmu-Ilmu Keislaman, 36(1), 154173. 